\title{
The Application of Problem-Based Learning Model to Increase Students' Activity and Learning Outcomes in Basic Process of Metal Treatment
}

\author{
Ambiyar, Arwizet Kaharudin, Refdinal, Mia Hermawati \\ Mechanical EngineeringDepartment, Engineering Faculty \\ Universitas Negeri Padang \\ Padang, Indonesia \\ ambiyar@ft.unp.ac.id
}

\begin{abstract}
Based on the researcher survey, it appears that many students were passive, daydreaming, and busy with cellphone and non-related activities during the learning process. The purpose of this research is to improve learning activities and learning outcomes through the implementation of Problem-Based Learning model. This study is a classroom action research consists of two cycles. Each cycle consists of two meetings. The data were collected using observation to see the changes in learning activities and test was utilized for measuring students' learning outcome. Based on the observations, the average learning activities of the first and second cycles were $61.93 \%$ and $80.0 \%$. Students' learning outcomes were also increased classically. In the first cycle, $59.25 \%$ or 16 students have achieved the minimum criteria of mastery, and in the second cycle, $81.84 \%$ or 22 students have achieved the minimum criteria of mastery. This means, the implementation of Problem-Based Learning method can increase student activities and learning outcomes in the basic process of metal treatment subject.
\end{abstract}

Keywords-classroom action research, learning activity, learning outcome, problem based learning, basic process of metal treatment subject.

\section{INTRODUCTION}

Students educated for the world of the 21 st century must develop habits of thinking, researching, and problem solving to succeed in a rapidly changing world. In the era of globalization, traditional education system is losing its relevance. [1]. Education plays a role in preparing quality human resources. In the education process, there are three elements that determine the teaching process that are teachers, students and the curriculum used. Vocational High School is an educational institution that prints beginner level work institute, towards skilled level labor in certain field. The main purpose of the learning process at Vocational High School is to demand the students succeed in applying the theoretical and practical abilities. This is in line with the objectives of the Vocational High School which is to produce middle-skilled workers in their fields supported by satisfactory learning outcomes. Learning outcomes can be viewed as one measurement of students' success in schooling and are taken into consideration in determining students' abilities.

The Basic Process of Metal Treatment is one of the eyes of productive training with theory learning. This course aims to provide knowledge to students about the science of metal starting from elements, properties, to the manufacture and metal processing. Based on a survey conducted at Vocational High School Muhammadiyah 1 Padang, it appears that in the learning process students were less active and less attentive to teaching materials presented by teachers, many students were passive, daydreaming, playing cellphone, noisy, and busy themselves with the activities. The result of this student activity was reflected in the learning result obtained at the Basic Metal Treatment Process Training, the Minimum Criteria score specified in Vocational High School Muhammadiyah 1 Padang is 80 . Students' learning outcomes in the eye of the process The Basic Process of Metal Treatment has not met the Criteria of Minimum Completeness, as shown in the following table.

TABLE I. Mid SEMESTER II GRADE OF Class X STUdENTS AT Basic Process of Metal Treatment at Vocational High SCHOOL MUHAMMADIYAH 1 PADANG 2016/2017

\begin{tabular}{|l|c|c|c|}
\hline \multirow{2}{*}{$\begin{array}{c}\text { Students } \\
\text { of class X }\end{array}$} & \multicolumn{3}{|c|}{ Mid Semester II Grade of Class X } \\
\cline { 2 - 4 } & $\begin{array}{c}\text { Students with } \\
\text { value average } \\
\mathbf{2} \boldsymbol{8 0}\end{array}$ & $\begin{array}{c}\text { Students with } \\
\text { value average } \\
<\mathbf{8 0}\end{array}$ & $\begin{array}{c}\text { Students } \\
\text { do not follow } \\
\text { exam }\end{array}$ \\
\hline 27 & $10(37.04 \%)$ & $13(48.15 \%)$ & $4(14.81 \%)$ \\
\hline
\end{tabular}

Table I shows the total of 27 students of class $\mathrm{X}$ of Engineering Department of Engineering in the Basic Process of Metal Student Process in Vocational High School Muhammadiyah 1 Padang academic year 2016/2017, as many as 10 students (37.04\%) achieved the basic learning process of metal treatment sufficient to graduation requirements. Meanwhile, 13 students $(48.15 \%)$ did not meet the standard of graduation and 4 other students (14.81\%) did not take the test.

The low learning outcomes obtained by students is thought to be the result of the teaching method used by the teacher. The teaching method used by the teacher, in this case, is only centered on the teacher (teacher-centered). According to [2], this learning strategy quickly spurred the students' boredom to learn, making it difficult for teachers to see changes in students' activity in learning and can lead to low learning outcomes due to the use of more focused learning time to complete learning materials.

In response to the above conditions, it is necessary to improve the quality of learning in terms of the basic process of metal treatment through the application of a model of 
learning that can stimulate the level of students' activeness and focus attention on training. One of the learning models used in improving the quality of learning on the subject of basic metal treatment process is the Problem Based Learning (PBL) model.

Problem-based learning is an ideal learning approach that can be used to help students determine solutions to nonroutine problems [3]. PBL encompasses "active learning with particular relevance to the learning objectives (as opposed to the traditional passive spoon-feeding rote learning based on teacher-designed didactic lectures and instruc $\neg$ tions) [4]. During the PBL process, students can work together to find solutions to complex problems [5]. Therefore, constructivist theories refer to student-centered learning. PBL includes student-centered learning for problem solving [6] and students are exposed to complex problems [7]. Thus, the PBL model is a learning approach that teachers can use to help students solve problems they face either individually or in groups.

PBL Model is "a method of instruction that develops learners' knowledge and problem-solving skills through realworld problems" [8]. Problem-based learning is both problem-centered and learner-centered in a dynamic process whereby students are actively involved in posing and solving problems related to the content and context under investigation. Students are no longer passive learners, but active participants in their learning. The PBL model is also a student-centered approach, thus actively develop knowledge and skills in solving problems. This has been supported by [9] who stated that "educational research demonstrates that active learning is the most effective technique for students to learn, apply, integrate, and retain information".

The results of research conducted by [10]-[11] noted that Problem Based Learning can improve the students' learning independence, interests and achievement. Sari and Mukhadis obtained the results of the research achievement of the PBL model was better than the one after the use of Expository learning. This means the PBL model is an effective technique for enabling students in learning and simultaneously influencing their learning outcomes. In the learning process, students need to understand the nature of learning. Davis (2000) stated that the essence of learning is the willingness of students to learn not only based on what is given by the teacher alone [12].

\section{METHOD}

The type of research the authors do is classroom action research [13-15]. This study consists of two cycles. In each cycle, there are four stages in the implementation, namely planning, action, observation and reflection. This study was conducted in two cycles for 4 weeks, which in 1 cycle consists of 2 meetings and in 2 weeks, 2 times face-to-face meeting.

This research was conducted to increase the activity and learning outcomes of X Class students of Mechanical Engineering of metal treatment basic process through applying Problem-Based Learning model. The study was conducted by observation and collective assessment of the students' activities in the learning stages to see the increase of activity and the students' learning outcomes after the implementation of this problem-based learning model. Test results of learning at each end of the cycle in the form of objective tests were conducted first analysis of items to determine the level of difficulty and distinguishing power problem as well as looking for grain validity and reliability value. Observation aspects of students' activities used in the observation sheet are as follows.

TABLE II. Aspect of Students Activity ObSERVATION SheEt

\begin{tabular}{|c|c|c|c|}
\hline \multicolumn{4}{|c|}{ Students' Activity Observation Sheet } \\
\hline No & Indicator & Sub Indicator & Item \\
\hline \multirow[t]{2}{*}{1} & \multirow[t]{2}{*}{$\begin{array}{l}\text { Students follow the } \\
\text { lesson well }\end{array}$} & $\begin{array}{l}\text { Students sit in groups } \\
\text { immediately after the group is } \\
\text { divided }\end{array}$ & 1 \\
\hline & & $\begin{array}{l}\text { Students pay attention when the } \\
\text { teacher explains learning / } \\
\text { giving direction }\end{array}$ & 2 \\
\hline \multirow[t]{2}{*}{2} & \multirow[t]{2}{*}{$\begin{array}{l}\text { Students identify } \\
\text { problems given by } \\
\text { the teacher }\end{array}$} & $\begin{array}{l}\text { Students read the Student } \\
\text { Worksheet provided by the } \\
\text { teacher }\end{array}$ & 3 \\
\hline & & $\begin{array}{l}\text { Students can work with their } \\
\text { group's friends to find answers } \\
\text { to the given Student Worksheet }\end{array}$ & 4 \\
\hline 3 & $\begin{array}{l}\text { Students record the } \\
\text { concepts used in } \\
\text { problem solving }\end{array}$ & $\begin{array}{l}\text { Students create } \\
\text { problem- } \\
\text { solving reports of their } \\
\text { discussion } \\
\text { results }\end{array}$ & 5 \\
\hline \multirow[t]{2}{*}{4} & \multirow{2}{*}{$\begin{array}{l}\text { Students look for } \\
\text { various information } \\
\text { needed in problem } \\
\text { solving }\end{array}$} & $\begin{array}{l}\text { Students read the handouts } \\
\text { given by the teacher }\end{array}$ & 6 \\
\hline & & $\begin{array}{l}\text { Students ask if there is anything } \\
\text { that is not understood in } \\
\text { working the Student Worksheet }\end{array}$ & 7 \\
\hline 5 & $\begin{array}{l}\text { Students deliver } \\
\text { problem solving } \\
\text { results }\end{array}$ & $\begin{array}{l}\text { Students dare to present the } \\
\text { results of their discussion to be } \\
\text { presented and other students } \\
\text { listen to the presenter's students } \\
\text { during the presentation }\end{array}$ & 8 \\
\hline \multirow[t]{3}{*}{6} & \multirow[t]{3}{*}{$\begin{array}{l}\text { Students actively } \\
\text { respond to problem- } \\
\text { solving results by } \\
\text { respecting and } \\
\text { accepting other } \\
\text { people's opinions }\end{array}$} & $\begin{array}{l}\text { Students dare to raise their } \\
\text { hands and responding to the } \\
\text { results of the discussion of the } \\
\text { presenter or presenter group } \\
\text { trying to answer other group } \\
\text { questions }\end{array}$ & 9 \\
\hline & & $\begin{array}{l}\text { Students speak politely when } \\
\text { expressing their opinions or } \\
\text { questions }\end{array}$ & 10 \\
\hline & & $\begin{array}{l}\text { Students can defend their } \\
\text { opinions for logical reasons or } \\
\text { can accept the presenter's } \\
\text { answer }\end{array}$ & 11 \\
\hline 7 & $\begin{array}{l}\text { Students record the } \\
\text { result of problem } \\
\text { solving that has been } \\
\text { concluded together }\end{array}$ & $\begin{array}{l}\text { Students record the conclusions } \\
\text { of problem-solving results in } \\
\text { the notebook }\end{array}$ & 12 \\
\hline
\end{tabular}

The data on the observation sheet of students' learning activity were analyzed by quantitative means resulting in percentage form. To see the percentage of student activity each cycle used the following formula:

$$
\mathrm{P}=\frac{\sum X}{\sum Y} \times 100 \%
$$

Description:

P: Percentage of activity observed at each meeting

$\Sigma \mathrm{X}$ : Total student activity score

$\Sigma Y$ : Maximum number of activity scores

Furthermore, the percentage information obtained was used as an interpretation of assessment students activity that was guided by the following categories [16]. 
TABLE III. AsPect OF STUdents Activity ObSERVATION SheEt

\begin{tabular}{|l|l|l|}
\hline No & \multicolumn{1}{|c|}{ Interval } & \multicolumn{1}{c|}{ Category } \\
\hline 1 & $\geq 75,6 \%$ & Active \\
\hline 2 & $59,6 \%-75,5 \%$ & Quite active \\
\hline 3 & $\leq 59,5 \%$ & Less active \\
\hline
\end{tabular}

Meanwhile, to obtain the percentage of assessment of learning outcomes, the formula below was used:

1) Individual mastery

$$
\mathrm{NI}=\frac{T}{S M} \times 100 \%
$$

$$
\begin{aligned}
& \text { Description: } \\
& \mathrm{NI}=\text { complete learning individually } \\
& \mathrm{Q}=\text { Scores obtained by students } \\
& \mathrm{SM}=\text { The maximum score of the test }
\end{aligned}
$$

This individual learning mastery refers to the provisions set in the Muhammadiyah 1 Padang Vocational High School curriculum that is equal to 80 .

2) Classical Mastery

$$
\mathrm{NI}=\frac{T}{S M} \times 100 \%
$$

$$
\begin{aligned}
& \text { Description } \\
& \mathrm{NT}=\text { Mastery learning classically } \\
& \text { ST }=\text { Number of students who mastery the study } \\
& \mathrm{N} \quad=\text { Number of all students in one class }
\end{aligned}
$$

The mastery learning classically was achieved when the classical completeness grade value has reached the percentage value of $80 \%$.

This research can be said to be successful and can be stopped if it has reached the desired indicator. The indicator of the successful implementation of the action to improve the quality of learning can be determined by the teacher, in this case is the researcher himself, according to students' ability and the level of improvement to be achieved. The criteria of success in improving the quality of learning in research through the application of problem-based learning are: (1) Learning activities: (a) In the first cycle, students' learning activities reached a percentage of $60 \%$, and (b) In the second cycle, students' learning activity reached a percentage of $80 \%$, (2) Learning outcomes: (a) In the first cycle, students' learning outcomes reached a percentage of $50 \%$, and (b) In cycle II, students' learning outcomes reached a percentage of $80 \%$.

\section{Result AND DisCUSSION}

This study was conducted in 2 cycles consisting of 2 meetings in each cycle. Based on the action that has been done in cycle I it was known that the activity and student learning outcomes have achieved the success indicator of action in cycle I. Where students activeness was taken through activity observation sheet with the percentage value of $61.93 \%$ and classical classical completeness value taken based on the test at the end of the first cycle of $59.25 \%$.

The weakness found in cycle I was at meeting 1 where the group division process was rowdy and lasts long enough for 15 minutes. This is because the group divided in the learning meeting was not prepared before by the teacher as a researcher so that time consuming lessons caused the presentation can not be held at meeting 1. Presentation conducted in cycle I provided a short enough time for each group to do question and answer i.e only for 5 minutes for each group with a total of 5 groups. In addition, the presence of 2 new students at the presentation stage led to the unfavorable understanding of the students on teaching materials in cycle I so that the students' activity was classified as less active and the results of the students' learning test have not fulfilled the Minimum Criterion of Mastery which was set at 80 .

To improve the learning process in order to increase the students' activity in the next cycle and increase the activity in the observation aspect, especially the aspect belonged to the less active category in order to achieve the success indicator in the next cycle, the result of the student learning test at the end of cycle I was used to divide the students into several groups were heterogeneous in order not to re-take the time of discussion and group presentation. Meanwhile, the actions taken in cycle II have been able to increase learning activities and students' learning outcomes of the basic metal treatment process. This was evidenced by the increase in student activity to $80.03 \%$ and students' learning completeness classically increased to $81.48 \%$.

Here is a discussion or analysis of the action learning using problem-based learning model.

\section{A. Increased Students Learning Activity}

Learning activities are activities undertaken by students in learning process [17]. Learning activity of the training of metal basic treatment process in this case is the activity done by the students in the learning process in the eye of the basic metal treatment process. In the learning process, activity is a very important principle, because learning will never exist without learning activities. As a rationality it also received recognition from various educational experts.

Rosseau explained that in the learning process, all that knowledge must be obtained by self-observation, selfexperience, self-inquiry, by self-employment, with selfcreated facilities, both spiritually and technically. Learning activities are efforts or ways to enhance and optimize the learning activities of students in the learning process. Learning activities are basically an effort to develop all the potential that exists in students, both spiritually potential and physically potential. Without any activity, learning process is impossible. Thus, students' activity is very necessary in the learning process.

The implementation of learning cycle I obtained the average activity of students in quite active category which then increased in cycle II into active category. From cycle I to cycle II, students seemed more active in the discussion process and sought answers from the given Student Worksheet. When students did not understand the material, students started to ask the teacher and responded to the existing questions in a better way and read the handouts well to find the results of problem solving on the Student Worksheet. Visible students began to work together in the process of discussion and dared to present the results of discussion.

In the Problem-Based Learning model, students communicate and cooperate in solving a problem. In 
addition, group learning provides an opportunity for students to define joint problem-solving strategies. Each student is expected to be active during the learning process. Based on the research that has been done, it can be concluded that the use of Problem-Based Learning model can increase students' activity. Increased students' activity in this study was evidenced by the increase of students' activity from cycle I to cycle II which has reached the success indicator of action like presented in the table 4 below:

TABLE IV. The Percentage of INCREASING StUdents ACtivity IN EACH OBSERVATION ASPECT FROM CyCLE I TO CYCLE II

\begin{tabular}{|l|l|l|l|}
\hline \multicolumn{1}{|c|}{ Aspects of Observation } & \multicolumn{3}{|c|}{ Percentage (\%) } \\
\cline { 2 - 4 } & $\begin{array}{c}\text { Cycle } \\
\text { I }\end{array}$ & $\begin{array}{c}\text { Cycle } \\
\text { II }\end{array}$ & $\begin{array}{c}\text { Enhancement } \\
\text { \% }\end{array}$ \\
\hline $\begin{array}{l}\text { Students sit in groups } \\
\text { immediately after the group } \\
\text { is divided }\end{array}$ & 54,55 & 65,25 & 10,7 \\
\hline $\begin{array}{l}\text { Students pay attention when } \\
\text { the teacher explains learning } \\
\text { /giving direction }\end{array}$ & 54,55 & 65,25 & 10,7 \\
\hline $\begin{array}{l}\text { Students read the Student } \\
\text { Worksheet provided by the } \\
\text { teacher }\end{array}$ & 54,55 & 65,25 & 10,7 \\
\hline $\begin{array}{l}\text { Students can work with their } \\
\text { group's friends to find } \\
\text { answers to the given Student }\end{array}$ & 54,55 & 65,25 & 10,7 \\
\hline $\begin{array}{l}\text { Worksheet } \\
\text { Students read the handouts } \\
\text { given by the teacher }\end{array}$ & 54,55 & 65,25 & 10,7 \\
\hline $\begin{array}{l}\text { Students ask if there is } \\
\text { anything that is not } \\
\text { understood in working the } \\
\text { Student Worksheet }\end{array}$ & 54,55 & 65,25 & 10,7 \\
\hline $\begin{array}{l}\text { Students dare to present the } \\
\text { results of their discussion to } \\
\text { be presented and other } \\
\text { students listen to the } \\
\text { presenters students during } \\
\text { the presentation }\end{array}$ & 54,55 & 65,25 & 10,7 \\
\hline $\begin{array}{l}\text { Students dare to raise their } \\
\text { hands thesponding to the results } \\
\text { and respon } \\
\text { of the discussion of the } \\
\text { presenter or presenter group } \\
\text { trying to answer other group } \\
\text { questions }\end{array}$ & 54,55 & 65,25 & 10,7 \\
\hline $\begin{array}{l}\text { Students can defend their } \\
\text { opinions for logical reasons } \\
\text { or can accept the presenter's } \\
\text { answer }\end{array}$ & 54,55 & 65,25 & 10,7 \\
\hline $\begin{array}{l}\text { Students record the } \\
\text { conclusions of problem- } \\
\text { solving results in the } \\
\text { notebook }\end{array}$ & 54,55 & 65,25 & 10,7 \\
\hline $\begin{array}{l}\text { Average } \\
\text { Student learning activity }\end{array}$ & 61,93 & 80,03 & 18,1 \\
\hline
\end{tabular}

Table IV shows the percentage of each aspect of observation as expected. The results of calculation in cycle II also showed the average activity has met the $80 \%$ success indicator.

Based on the research that has been done, it can be concluded that the use of problem-based learning model can increase students' activity. In the table 5 below, the increased students' activity in this study is evidenced by the increased activity of students' activity from cycle I to cycle II which has reached the indicator of the success of the action specified as listed.
TABLE V. ACHIEVING THE SUCCESS OF ACTION RESEARCH FOR STUDENTS' LEARNING ACTIVITIES

\begin{tabular}{|l|l|l|l|l|}
\hline No & Cycle & $\begin{array}{c}\text { Action } \\
\text { Success } \\
\text { Indicator } \\
\text { (\%) }\end{array}$ & $\begin{array}{c}\text { Research } \\
\text { Results (\%) }\end{array}$ & $\begin{array}{c}\text { Description of } \\
\text { Action Success }\end{array}$ \\
\hline 1 & I & 60 & 61,93 & success \\
\hline 2 & II & 80 & 80,03 & success \\
\hline
\end{tabular}

The findings of this study support the findings of other studies [18] student-centered PBL-it fosters active learning, improved understanding, and retention and development of lifelong learning skills. In addition, PBL is well-suited to help students become active learners since it situates learning in real-world problems and makes them responsible for their learning [19]. Applying problem-based learning increase students' participation in class activities and enhance critical thinking skills [20]. Some researchers found a significant correlation between problem-based learning activities and the critical thinking skills that students will need in the $21 \mathrm{st}$ century [21].

\section{B. Improvemenr of Students Learning Outcomes in Basic Process of Metal Treatment}

The data has been obtained based on the results of research, it is known that there was an increase in the number of students who achieved the Minimum Criterion of Mastery score of 80 . Of the total of 27 students, in cycle I as many as 16 students expressed in learning with the value reached the Minimum Criterion of Mastery and in cycle II, the number of students increased to 22 students, while 3 students who scored 0 were those who never attended from the beginning of the meeting in this study considered as incomplete. Based on the research that has been done, it can be concluded that the use of problem-based learning model can improve students' learning outcomes. The table 6 below shows the improvement of this learning result evidenced by the increase of classical completeness from cycle I to cycle II which has reached the indicator of the success of the action specified.

TABLE VI. ACHIEVING THE SUCCESS OF ACTION RESEARCH FOR STUDENTS' LEARNING ACTIVITIES

\begin{tabular}{|l|l|l|l|l|}
\hline No & Cycle & $\begin{array}{c}\text { Action } \\
\text { Success } \\
\text { Indicator } \\
(\%)\end{array}$ & $\begin{array}{c}\text { Research } \\
\text { Results (\%) }\end{array}$ & $\begin{array}{c}\text { Description of } \\
\text { Action Success }\end{array}$ \\
\hline 1 & I & 50 & 59,25 & success \\
\hline 2 & II & 80 & 81,48 & success \\
\hline
\end{tabular}

Based on table 6 it is known that the success indicator for each cycle has been achieved indicating that the action of applying problem-based learning in this research can improve students' learning result of X class of Mechanical Engineering at Vocational High School Muhammadiyah 1 Padang on the basic metal treatment process. The findings of this study support the findings of other studies [20] that by applying the PBL model can improve learning outcomes.

\section{CONCLUSION}

Based on the results of data analysis obtained in this study, it can be drawn conclusion as follows: (1) application of problem-based learning model can increase students' 
activity. The increase of this activity was evidenced by the increase of students' activity from cycle I of $61.93 \%$ with the active enough category to $80.03 \%$ in cycle II with active category, and (2) Application of problem-based learning model can improve students' learning outcomes. The improvement of this learning result was evidenced from the increase of classical completeness that was previously in the first cycle of $59.25 \%$ with 16 well-completed students in cycle II to $81.48 \%$ with 22 students completed from a total of 27 students.

Based on the results of the research, suggestions for teachers in applying the PBL model to be integrated effectively in learning include: clearly define the purpose of doing PBL, hold brainstorming sessions, develop illstructured problems, refrain from providing information, allow time for collaboration, emphasize depth over breadth, conduct regular assessment, hold class discussions, facilitate peer feedback, and assess authentically.

\section{REFERENCES}

[1] Upasana, KM. A Comparative Study of Taditional Education and eEducation with Special Reference to India. International Journal of Research in Business Management. Vol.2, Issues, May 2014, pp. 149162.

[2] Sudjana. Metode dan Teknik Pembelajaran Partisipatif. Bandung: Falah. 2010.

[3] Strobel, J., \& van Barneveld, A. When is PBL more effective? A meta-synthesis of meta-analyses comparing PBL to conventional classrooms. Interdisciplinary Journal of Problem-Based Learning, 3(1), 2009, pp. 44-58. https://doi.org /10.7771/1541-5015.1046

[4] Kwan, C.Y. (2000) "What is Problem Based Learning (PBL)?." CDTL Brief, 3:3 (2009), 1-2. Last modified 2009 http://www.cdtl.nus.sg/Brief/Pdf/v3n3.pdf

[5] Ferreira, M. M., \& Trudel, A. R. The impact of problem-based learning (PBL) on student attitudes toward science, problem-solving skills, and sense of community in the classroom. Journal of Classroom Interaction, 2012, 47 (1), 23-30.

[6] Savery, J. R.. Overview of problem-based learning: Definitions and distinctions. Interdisciplinary Journal of Problem-Based Learning, 1(1), 2006, pp.9-20. https://doi.org/10.7771/1541-5015.1002

[7] Hmelo-Silver, C. E.. Problem-based learning: What and how do students learn? Educational Psychology Review, 16 (3), 2004, pp.235-266. https://doi.org/10.1023/B:EDPR .0000034022.16470.

[8] Pecore, J. L. Beyond beliefs: Teachers adapting problem-based learning to preexisting systems of practice. Interdisciplinary Journal of Problem-Based Learning, 7(2), 2012, pp.6-33.

[9] Burch, K. PBL, politics, and democracy. In B. Duch, S. Groh, \& D. Allen (Eds.), The power of problem-based learning: A practical "how to" for teaching undergraduate courses in any discipline. Sterling, VI: Stylus Publishing. 2001, pp.193-205. Retrieved from http://www.jciuh.org/issues/abstracts-47.1.pdf.

[10] Suparman. Peningkatan Kemandirian Belajar dan Minat Belajar Mahasiswa Mata Kuliah Elektronika Analog dengan Pembelajaran PBL. Jurnal Pendidikan Teknologi dan Kejuruan. 22.1, 2014. pp.8388.

[11] Wastono, FX. Peningkatan Kemandirian Belajar Siswa SMK pada Mata Diklat Teknologi Mekanik dengan Metode Problem Based Learning. Jurnal Pendidikan Teknologi dan Kejuruan. 2015, pp.392401.

[12] Rusman. Model-Model Pembelajaran. Jakarta: PT. Raja Grafindo Persada.2013.
[13] Sanjaya, Wina. Penelitian Tindakan Kelas. Jakarta: Kencana. 2016.

[14] Masnur Muslich. Melaksanakan PTK (Penelitian Tindakan Kelas) itu mudah: pedoman praktis bagi guru profesional. Jakarta: Bumi Aksara. 2012.

[15] Kusumah, Wijaya, Dedi Dwitagama. Penelitian Tindakan Kelas. Jakarta: PT. Indeks. 2012.

[16] Memes, W. Perbaikan Pembelajaran Kalor di SLTP. Jurnal Pendidikan dan Pengajaran FKIP Negeri Singaraja. 2001.

[17] Hamalik, Oemar. Proses Belajar Mengajar. Jakarta: Bumi Aksara 2013.

[18] Sari V. P. E., dan Amat Mukhadis. The Effect of Problem-Based Learning with Gallery Project and Locus of Control on Learning Achievement. Jurnal Pendidikan Teknologi dan Kejuruan,Volume 23, Number 4, October 2017.pp,392-401.

[19] Wood. D. F. ABC of learning and teaching in medicine Problem based learning. Journal BMJ Vol. 326. 8 February, 2003.

[20] Joyce, Bruce, Marcia Well, Emily Calhoun. Models of Teaching, Boston: Pearson/Allyn and Bacon. 2009.

[21] Drew, Sally Valentino. Open up the ceiling on the common core state standards: preparing students for 21st-century literacy-now. Journal of Adolescent and Adult Literacy, 56(4), 321-330. doi: org/10.1002/JAAL.001452013.

[22] Nafiah, Yunin Nurun dan Wardan Suyanto. Penerapan Model Problem-Based Learning untuk Meningkatkan Keterampilan Berpikir Kritis dan Hasil Belajar Siswa. 2014. 